\title{
Gender perspective in flood risk management: a case study in Dodhara-Chandani areas of Kanchanpur district, far western Nepal
}

\author{
*Manisha Maharjan ${ }^{1}$ and Kabi Raj Paudyal ${ }^{2}$ \\ ${ }^{1}$ College of Applied Sciences Nepal, Anamnagar, Kathmandu, Nepal \\ ${ }^{2}$ Central Department of Geology, Tribhuvan University, Kirtipur, Nepal. \\ (*Email: manimaharjan24@gmail.com)
}

\begin{abstract}
Nepal is among the most vulnerable countries regarding climate-induced-disasters. Nepal is ranked $30^{\text {th }}$ among 198 countries in flood hazard. Climate change associated vulnerability is contextual and gender specific as it impacts men and women differently. It intensifies the socially created inequalities between men and women where women are always the worst victim for their gender differentiated roles and lack of access and control over resources.

This paper discusses gender perspective on climate induced disaster, its impact and adaptation in Dodhara and Chandani VDCs of the Kanchanpur district based on the both primary and secondary sources of data. The primary information was collected using structured questionnaire from 96 households, key informant interviews and focus group discussion in both VDCs. The meteorological data (30 years) particularly rainfall and temperature were analysed to see the rainfall pattern and temperature trends. Analysis of temperature data revealed increment of mean annual temperature by $0.02^{\circ} \mathrm{C}$ per year, which verified the increase in number of warmer days in the study area. The analysis of rainfall data confirmed that the rainfall trend was declining by $1.66 \mathrm{~mm}$ per year in monsoon. The average monsoon rainfall recorded in the Mahendranagar Station was $413.4 \mathrm{~mm}$ (19842013). However, people recently experience heavy rainfall in monsoon. Women were found dependent on men during disaster period. Although people were not practicing any scientific adaptive measures, a few people have knowledge regarding the disaster preparedness in both VDCs. Environmental impacts after flood period was also observed.
\end{abstract}

Keywords: Climate change, flood disaster, gender-perspective, environmental impact, far western Nepal

Paper Received: 05 May 2015

Paper Accepted: 23 December 2015

\section{INTRODUCTION}

Climate change, its impact and associated vulnerabilities at present, are the most burning issues worldwide. Intergovernmental Panel on Climate Change (IPCC), on 4th Assessment Report described that 'Warming of the climate system is unequivocal, as is now evident from observations of increases in global average air and ocean temperatures, widespread melting of snow and ice and rising global average sea level' (IPCC 2007). More importantly, impacts of climateinduced disasters are not gender neutral (Dankelman et al. 2008). Adaptation, vulnerability and resilience of people to climate change depend upon a range of conditions (Nellemann et al. 2011). Gender does not mean "women". However, in most societies the female gender is defined as having less power and fewer opportunities, liberty and rights than the male gender. Given this disadvantaged position in many countries, the promotion of gender equality implies a very specific attention to women's empowerment (UNDP 2010).

Disaster risk management (DRM) is a process for reducing, mitigating or preventing the risk of disaster. It involves orderly incorporating a number of strategies in areas of administration and management, within the community and in institutions and organizations, through policies, programs and projects to reduce the impact of natural hazards and other threats on people and the environment using structural and non-structural methods (UNISDR 2009).

Nepal is vulnerable to disasters. It ranks $11^{\text {th }}$ in risks from earthquakes and $30^{\text {th }}$ in hazard from floods among 198 countries. A UN Report showed that out of 75 districts in the country, 49 districts are prone to floods and/or landslides, 23 districts to wild fires and one to wind storms. A total of 64 out of 75 districts are prone to disaster of some types (Upreti et al. 2007). According to National Adaptation Program of Action (NAPA) to climate change, Nepal is exposed to various types of hydro-meteorological disasters which are likely to be further exacerbated by climate change. More than 4,000 people died in the last decade due to climate-induced disasters causing an economic loss of US\$5.34 billion in Nepal (MoE 2010).

Several studies have shown that disaster related death rates are higher among females than males and this is caused by differences in vulnerability of female and male which are the results of socially constructed roles. For example, during 1993 severe flooding in Sarlahi district of Nepal, flood related mortality is found higher for girls (13.1 per 1000) compared to boys (9.4 per 1000) and for women (6.1 per 1000) compared to men (4.1 per 1000) (Pradhan et al. 2007). Some researchers 
attributed this to societal concepts of masculinity that compelled men to feel they had to take very high risks in order to protect family, community lives and property (Dimitrijevics 2007). Neumayer and Plumper (2007) suggest that the impacts of climate change will also be gender differentiated. As with natural disasters, climate change is likely to exacerbate previously existing patterns of discrimination that, on average, render women more vulnerable to fatalities and reduce their life expectancy, especially for economically poor women, more than men.

The poverty experienced by millions of women and men is shaped by inequalities. The most prevalent of these inequalities, and the one which affects all communities, is gender inequality. Therefore, it is essential to review plans and policies which address climate-induced disaster risk reduction and management because the gender blind policies cannot address gender inequality and accordingly genderdifferentiated impacts. Furthermore, assessing knowledge of both male and females helps to identify knowledge gaps and modify existing awareness programs and their ways of dissemination accordingly. On the other hand, females are not just victims of climate-induced disasters; however, they demonstrate extraordinary powers of resilience during disasters and can also be powerful agents for change. Hence, understanding how gender relations shape women's and men's lives is critical to effective climate-induced disaster risk reduction and management in Nepal.

For the case study, the Dodhara and Chandani VDCs were selected, which lie in the Far Western Development Region of Nepal in Kanchanpur district and have an area of $1610 \mathrm{~km}^{2}$. The study area is situated between latitudes $28^{\circ} 49^{\prime} 32.98^{\prime \prime} \mathrm{N}$ to $28^{\circ} 58^{\prime} 51.98^{\prime \prime} \mathrm{N}$ and longitudes $79^{\circ} 52^{\prime} 40.83^{\prime \prime}$ to $80^{\circ} 09^{\prime} 59.45^{\prime \prime}$ E. The elevation of the study area ranges from about $300 \mathrm{~m}$ to $2,000 \mathrm{~m}$. The study was carried out with the objectives (i) to assess gender-differentiated impacts of flood in DodharaChandani VDCs, the most affected areas from flood. (ii) to assess knowledge and perception of males and females towards disaster risk reduction, adaptation and management on flood affected area, and (iii) to study the environmental impacts of flood in the Dodhara- Chandani area.

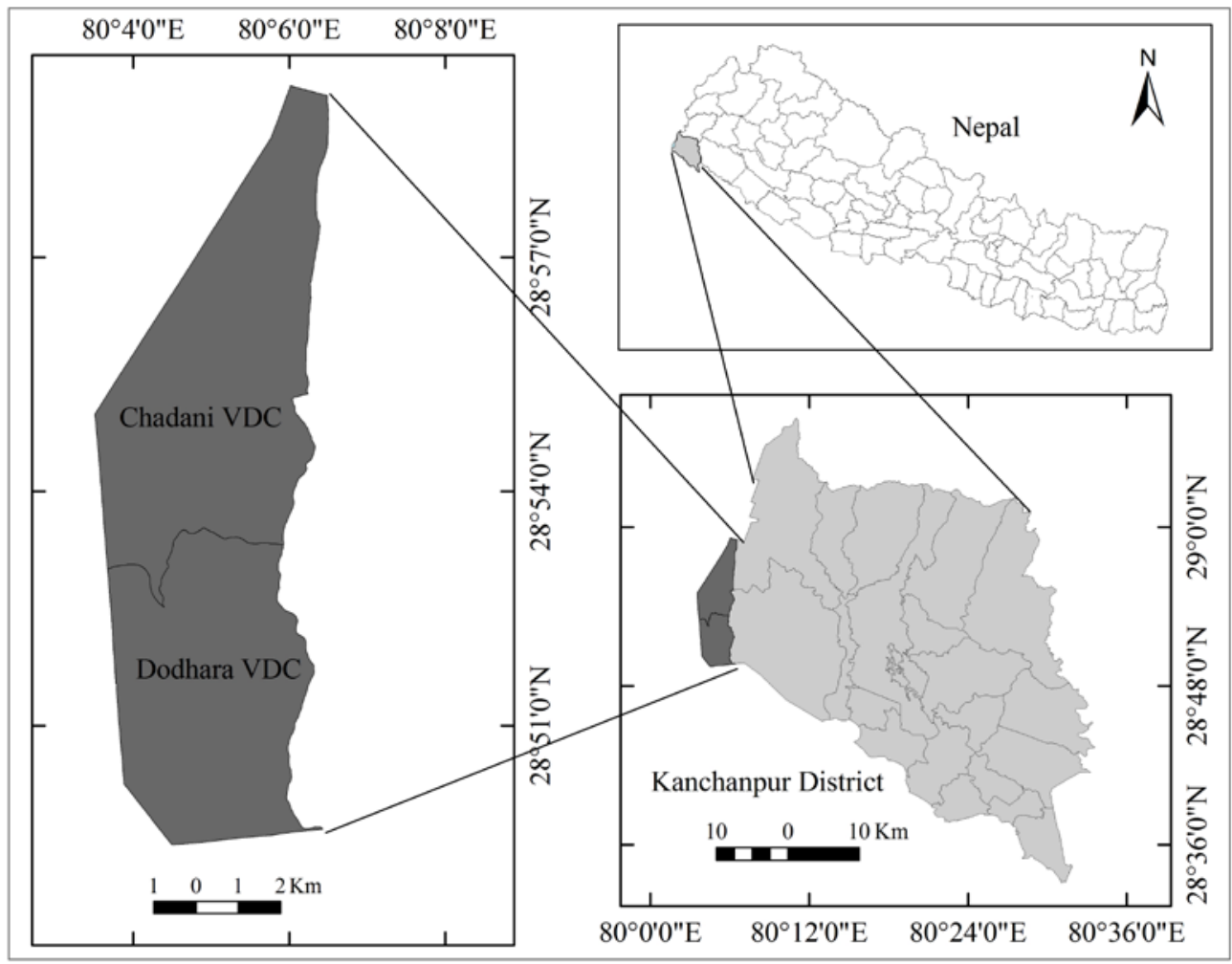

Fig. 1: Location map of the study area.

\section{METHODOLOGY}

Major elements of the methodology include the collection of primary and secondary information, field observation, key informant interviews and focus group discussions. After the review of literatures, sites were selected for field study. The study area was in the western side of the Shuklaphanta wildlife reserve along the Mahakali River. The household questionnaire survey was conducted in the study site with appropriate sample size. A formal and informal interview was also done with different key persons. After the sampling survey, the raw data were analyzed in MS Excel and presented in charts. 


\section{Sampling procedure}

The list of VDCs, their ward numbers and household population were obtained from CBS (Central Bureau of Statistics, Nepal) records, District Development Committee and VDC offices. The sample size (n) for the questionnaire survey was determined by using the following formula given by Arkin and Colton (1963) cited in Dangol (2007) at 95\% confidence level.

Sample size $(n)=\frac{N^{*} z^{2 * P}(1-P)}{N^{*} d^{2}+z^{2 * P}(1-P)}$

Where,

$$
\begin{aligned}
& \mathrm{N}=\quad \text { Total number of households } \\
& \mathrm{z}=\quad \begin{array}{l}
\text { value of standard variate at } 95 \% \text { confidence } \\
\text { level }(1.96)
\end{array} \\
& \mathrm{P}=\text { estimated population proportion }(0.1) \\
& \mathrm{d}=\quad \text { error limit of } 5 \%(0.05)
\end{aligned}
$$

The population data of the study area was collected from VDCs and with the application of above formula the sample size was established. From the sample size formula, the sample size (n) for Dodhara VDC was calculated which were 98 but 96 household was taken and similarly, the sample size (n) for Chandani was calculated which were 90 but 96 households were taken to insure equal inclusion of male and female in both VDCs.

\section{Data collection}

\section{Primary data collection}

A field survey was undertaken using various tools of data collection for the purpose of primary data collection as mentioned below.

\section{i. Structured interview}

A structured questionnaire was undertaken to family member of the selected households within the study areas. Only one member from one house that might be male or female was interviewed and equal numbers of males and females were surveyed in the study areas. Simple random sampling method was applied to gather information about climate change, vulnerability induced by climate change and adaptation measures used by locals to minimise such impacts.

\section{ii. Interview with key informants}

Similarly, key informants were identified in the region and interviewed. Such key informants included village elders, community leaders, representatives of various government bodies and institutions active in the region etc.

\section{iii. Field observation}

The field observation was focused on threats of climate change, various adaptation measures and techniques by communities to cope with flood. The field observation was undertaken in each ward of villages to observe the environmental impacts of flood.

\section{iv. Focus Group Discussion (FGD)}

Focus groups was conducted to collect information on household production, income and assets, as well as role of male and female during flood conditions and sources of information for decisions. A series of open-ended questions focusing on certain topic were discussed among the key informants and household personnel. The two different groups of men and women were gathered in both VDCs to collect the information.

\section{Secondary data collection}

The secondary data and information were collected from different sources (government offices, library, and internet) these include district profile, reports/booklets, and journals. Temperature and precipitation data were obtained from DHM and were analysed. Metrological station (station 105) is situated in latitude $29^{\circ} 02^{\prime} \mathrm{N}$ and longitude $80^{\circ} 13^{\prime} \mathrm{E}$, at the elevation of $176 \mathrm{~m}$. Data from 1984 to 2013 were used for the study. Various institutions as ICIMOD, UN Library, and Central Library of Tribhuvan University were also consulted for literatures including dissertations, newsletters, reports and journal articles that are relevant for the present study. Different organization like Red Cross, Action-Aid, DPNet etc. working in disasters were visited to gather materials as well as information.

\section{Data processing}

Some of the questions in the questionnaire were precoded and close-ended but most semi-closed and open-ended questions were also included. At first, all data was entered in the computer, using special packages including MS Excel. After entering into computer the data was carefully edited to find out the entry errors. All necessary tables of frequency and percentage was published as output for further analysis.

\section{Analysis and interpretation}

The analyses were based on descriptive analysis technique. Different analytical tools such as mean, median, cross tabulation, relational techniques, bar diagrams, graphs etc. were used.

\section{RESULTS}

\section{Knowledge about climate change}

The study didn't use complex scientific data to access climate variability and change. The study was more focused on to gain people's valuable perception and tried to link that with existing literature and scientific statements. Among the respondents, $44 \%$ male and $17 \%$ of female have heard about climate change where as $56 \%$ male and $83 \%$ female have not heard about climate change in the Dodhara VDC (Fig. 2). 


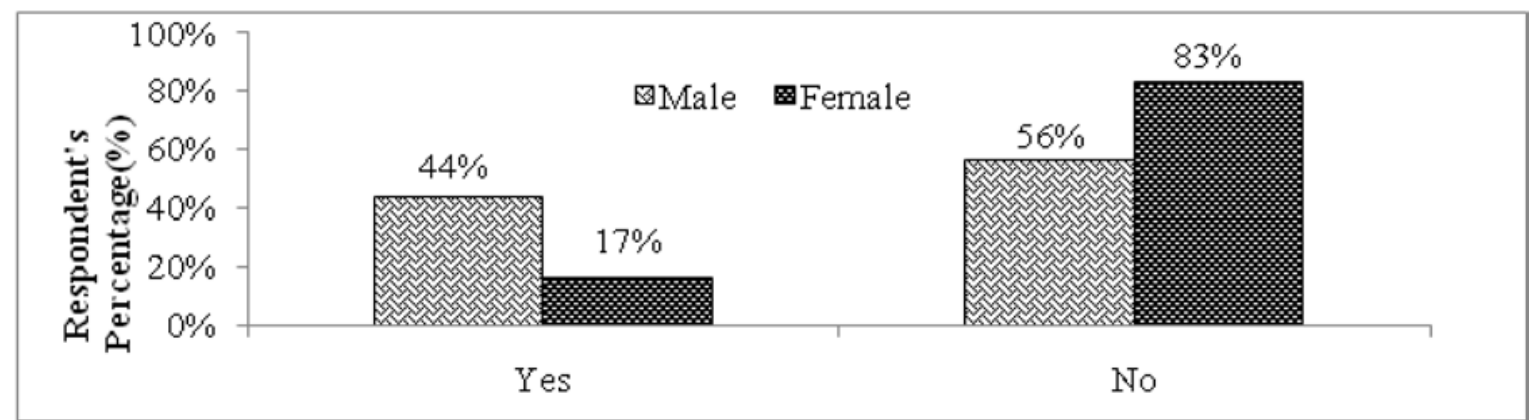

Fig. 2: Respondent's knowledge on climate change in Dodhara VDC.

Similarly $40 \%$ male and $15 \%$ of female have heard about heard about climate change in the Chandani VDC (Fig. 3). climate change where as $60 \%$ male and $85 \%$ female have not

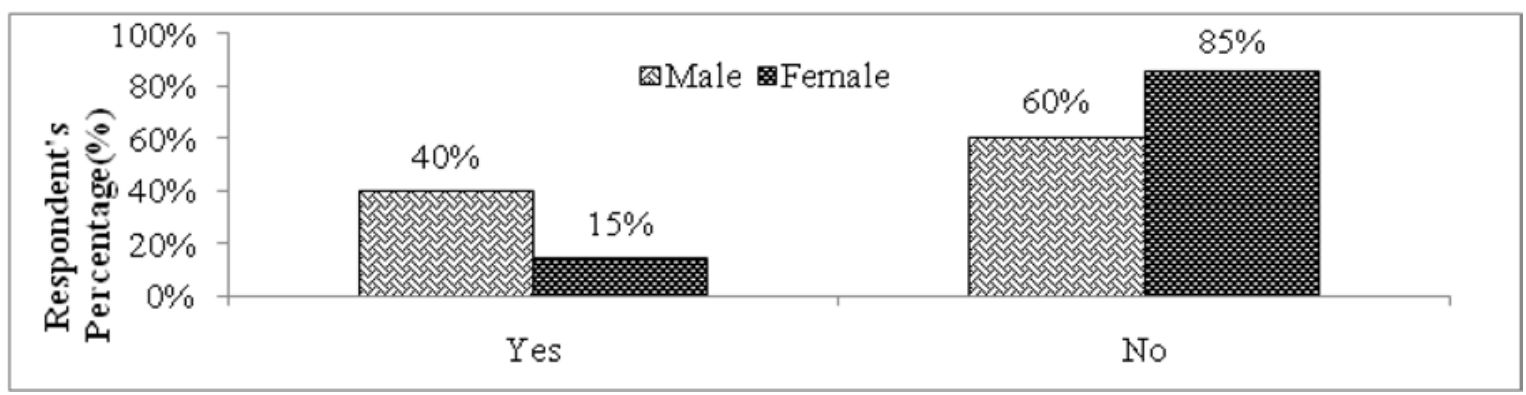

Fig. 3: Respondent's knowledge on climate change in Chandani VDC.

Through household survey, the respondents responded that they notice changes in their climate. In the Dodhara VDC, the highest response of male was in increased temperature during summer whereas most of the female responded in

Table 1: People's perception on noticed changes on climate.

\begin{tabular}{|l|l|l|l|l|}
\hline \multirow{2}{*}{\begin{tabular}{c}
\multirow{2}{*}{$\begin{array}{c}\text { Noticed changes in } \\
\text { climate }\end{array}$} \\
\cline { 2 - 5 }
\end{tabular}} & \multicolumn{3}{|c|}{$\begin{array}{c}\text { Desponse in percentage (\%) over } \\
\text { the study area }\end{array}$} \\
\cline { 2 - 5 } & Male & Female & Male & Female \\
\hline Long duration summer & 64.82 & 63.43 & 52.57 & 58.43 \\
\hline $\begin{array}{l}\text { Increased temperature } \\
\text { in summer }\end{array}$ & 85.42 & 78.52 & 60.46 & 74.29 \\
\hline $\begin{array}{l}\text { Monsoon with heavier } \\
\text { rainfall }\end{array}$ & 70.63 & 82.58 & 77.08 & 81.45 \\
\hline $\begin{array}{l}\text { No/less rainfall in Pre- } \\
\text { Post monsoon }\end{array}$ & 73.57 & 63.96 & 57.98 & 65.24 \\
\hline More water logged areas & 79.95 & 74.87 & 69.05 & 59.87 \\
\hline Winter with hotter days & 78.84 & 78.46 & 72.76 & 78 \\
\hline
\end{tabular}

monsoon with heavier rainfall. According to the elderly people especially from FGD, the summer days are hotter and winters are less cold and the winter rainfall has been decreasing recently.

Similarly, in the Chandani VDC, the highest response of male and female respondents was in monsoon with heavier rainfall. And the respondents from KII and FGD also noticed heavier rainfall in monsoon along with long and hotter days indicating change in local climate.

\section{Temperature and rainfall variability}

The annual and seasonal trend and variability of temperature and rainfall were analysed from the 30 years data.

\section{Pattern of rainfall}

The 30 years rainfall data of the Mahendranagar meteorological station was collected and seasonal and monthly trend analysis was done. Average annual monsoon season rainfall over past 30 years shows that it is in decreasing trend with erratic pattern. The average annual monsoon season rainfall is increasing at the rate of $0.2 \mathrm{~mm}$ per year (Fig. 4). 


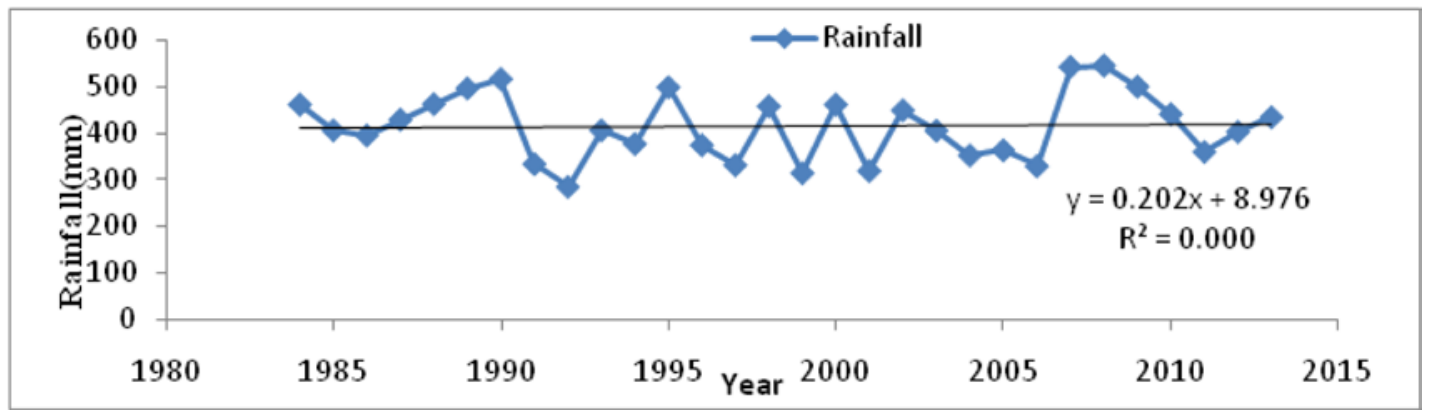

Fig. 4: Average annual monsoon rainfall trend.

Accordingly, 30 years' average monthly rainfall shows that August is the wettest month followed by July and September respectively (Fig. 5). In addition, if the monthly rainfall compared in decades, the rainfall in all of the months has decreased, especially in the case of monsoon it is decreasing at a higher rate, which might be the main cause of depletion of water sources.

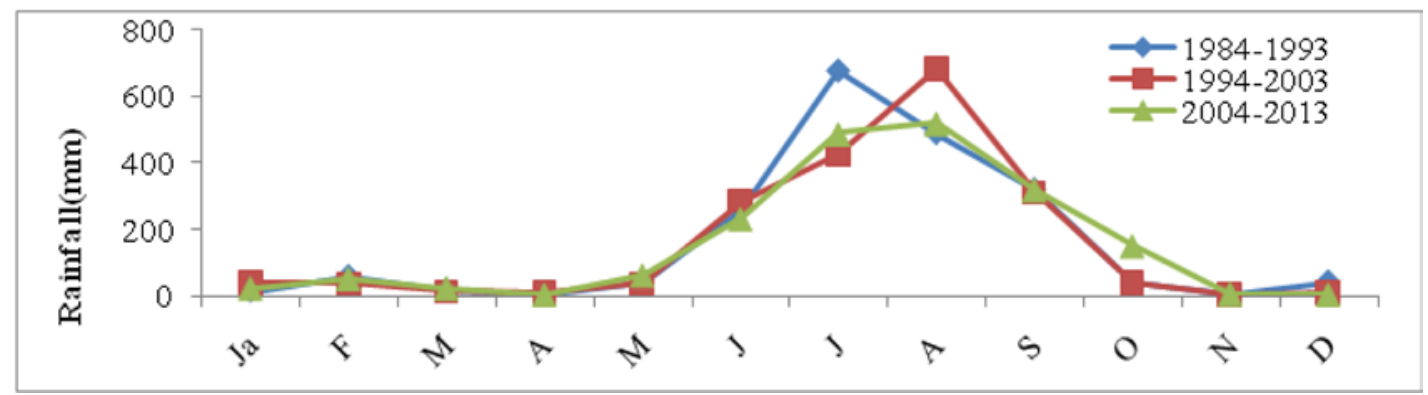

Fig. 5: Average monthly rainfall in decades.

\section{Temperature trend}

Rise in temperature is the direct indicator of climate change. In this study, monthly maximum and minimum temperature data was used as climatic indicator of changing climate for the villages. The mean annual temperature is in increasing at a rate of $0.02^{\circ} \mathrm{C}$ per year with highest temperature in the year 1998. The linear equation ( $\mathrm{Y}=0.022 \mathrm{x}-19.491)$ with $\left(\mathrm{R}^{2}=0.084\right)$ Fig. 6 shows increase in temperature.

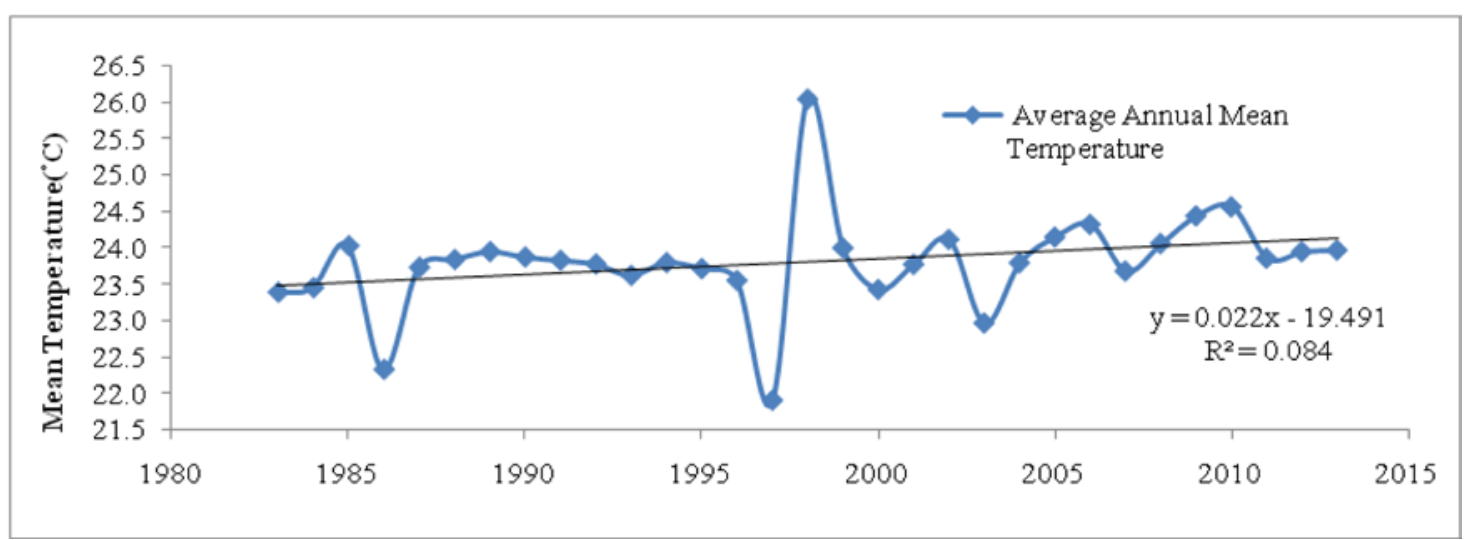

Fig. 6: Average annual mean temperature (1984-2013).

\section{Agriculture}

The respondents were inquired about the impact of climate change on agriculture. In Dodhara, all respondents disagreed in increase in productivity, $65 \%$ respondents agreed in low productivity and $35 \%$ respondents thought there was no effect on productivity (Fig. 7). 


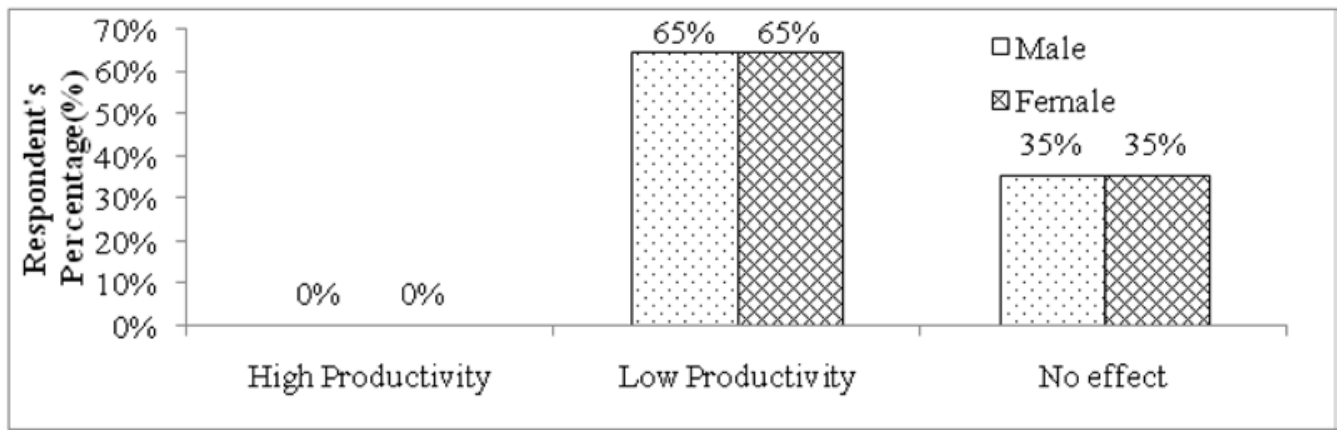

Fig. 7: Respondent's perception on impact in agricultural productivity in Dodhara VDC.

Further, the FGD in the Dodhara VDC concluded that the productivity of crop was decreasing. According to respondents, the main reasons for decreasing productivity were more rainfall during monsoon causing flood in agricultural land $(17 \%$ male and $22 \%$ female), long duration of water logging (16\% male and $19 \%$ female), no/less rainfall pre and post monsoon $(11 \%$ male and $9 \%$ female), decline of soil nutrients as flood destroys the top soil making it sandy and unfertile soil (23\% male and $21 \%$ female), bird interference (12\% male and $9 \%$ female), pests $(8 \%$ male and $8 \%$ female) and use of old seeds $(13 \%$ male and $12 \%$ female) (Fig. 8 ).

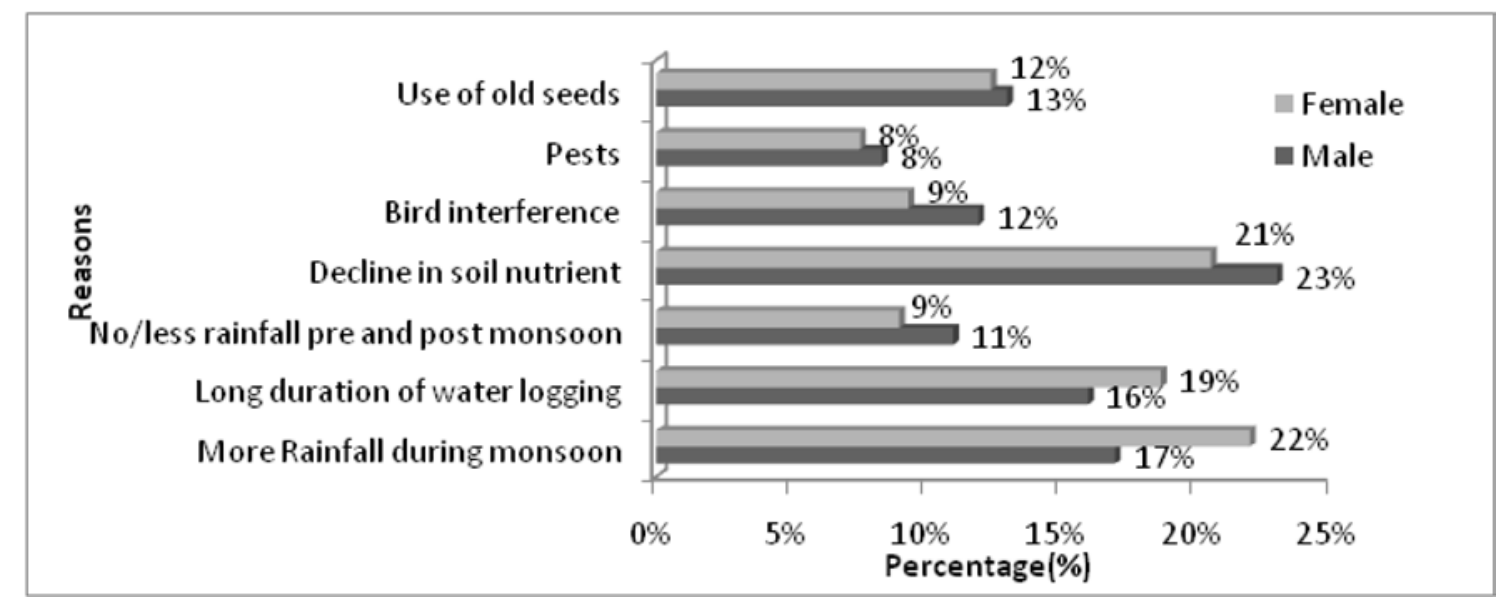

Fig. 8: Reasons for decline in agricultural yield.

In the Chandani VDC, all respondents disagreed in increase in productivity, $73 \%$ male and $71 \%$ female respondents agreed in low productivity and $27 \%$ male and $29 \%$ female respondents thought there was no effect on productivity (Fig. 9).

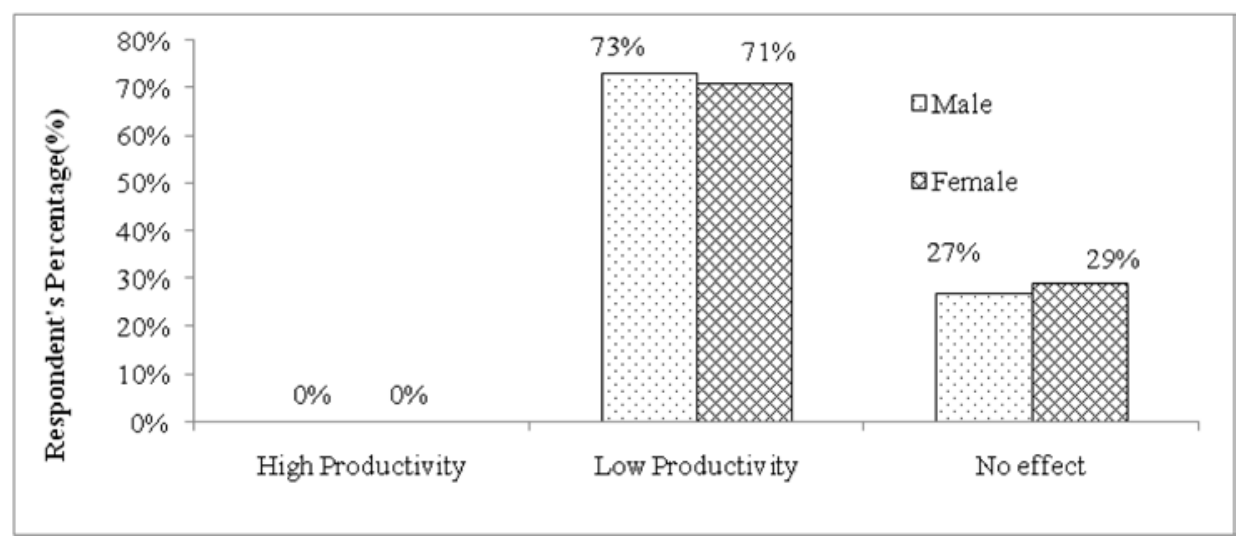

Fig. 9: Respondent's perception on impact in agricultural productivity in Chandani VDC. 
Further, discussion during FGD in the Chandani VDC concluded that the productivity of crop was decreasing. According to respondents participated in discussion the main reasons for decreasing productivity were more rainfall during monsoon causing flood in agricultural land $(19 \%$ male and $20 \%$ female), long duration of water logging (15\% male and
$14 \%$ female), no/less rainfall pre and post monsoon (18\% male and $20 \%$ female), decline of soil nutrients (19\% male and $20 \%$ female), bird interference ( $10 \%$ male and $8 \%$ female), pests ( $7 \%$ male and $8 \%$ female) and use of old seeds (12\% male and 10\% female) (Fig. 10).

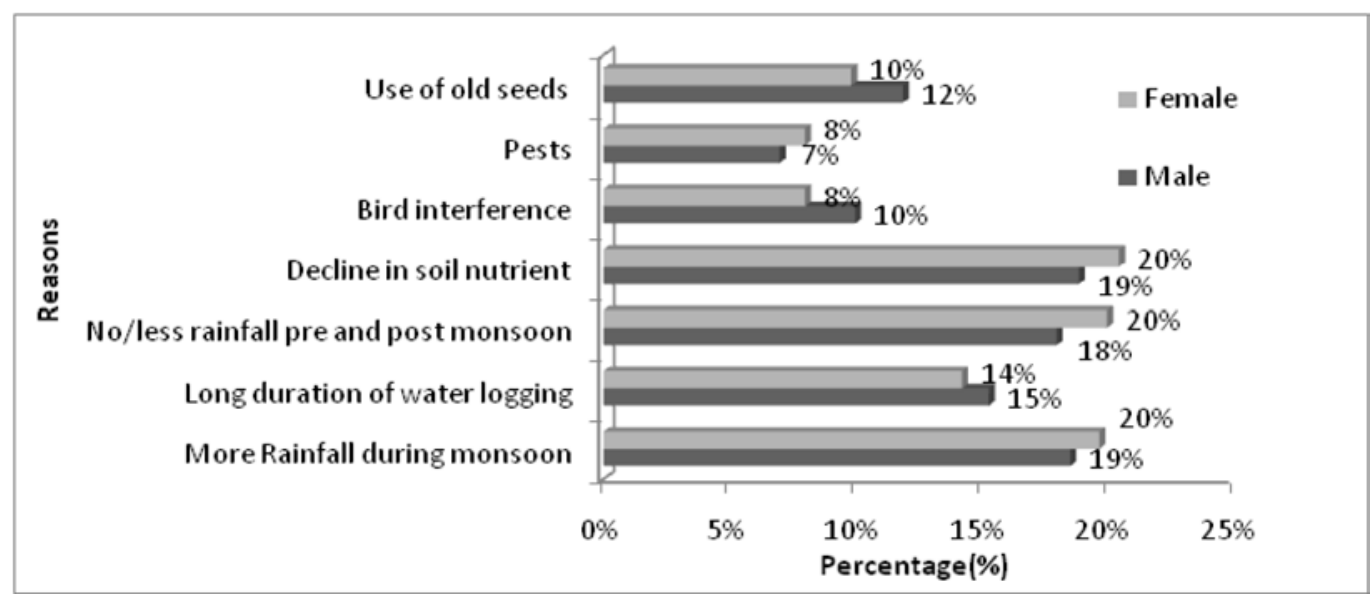

Fig. 10: Reasons for decline in agricultural yield.

\section{Gender differentiated vulnerability in climate change induced disasters}

Climate change is gender specific. Men and women experience climate change differently with varied magnitude of vulnerability. Different segments of society face climatic disaster differently where different members of a family experience climatic disaster with varied intensity. The study thus tried to explore people's perception on gender differentiated vulnerability in climate change induced disaster. Primary focus of the study was to understand who are the major victims of climate change and associated disasters in household level as well as community level.

It was found that $25 \%$ of male and $21 \%$ of female respondents perceived that all are equally vulnerable to climate change induced disasters as they thought that disasters are nt board to gender, economic status and physical strength. Majority of respondents i.e. 38\% male and 40\% female identified that women are vulnerable than others due to their physical strength, responsibility towards family as well as social boundaries and the elderly people and children who were vulnerable according to $29 \%$ of male and $29 \%$ of female respondents due to their physical strength. Only $8 \%$ male and $10 \%$ female respondents thought that poor are vulnerable due to their economic status (Fig. 11).

Similarly, it was found that $25 \%$ of male and $13 \%$ of female respondents perceived that all are equally vulnerable to climate change induced disasters as they thought that disasters don't gender, economic status and physical strength. Majority of respondents i.e. $46 \%$ male and $63 \%$ female identified that women are vulnerable than others due to their physical strength, responsibility towards family as well as social boundaries and the elderly people and children who were vulnerable according

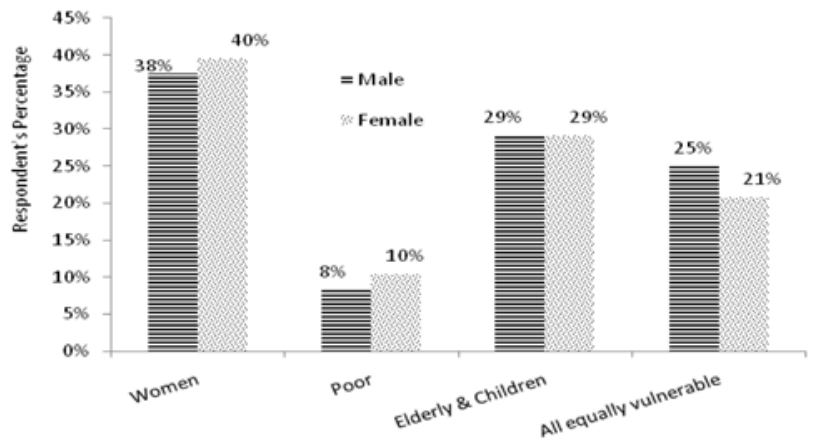

Fig. 11: Responses on gender differentiated vulnerability under climate change induced disasters in Dodhara VDC.

to $21 \%$ of male and $23 \%$ of female respondents due to their physical strength. Only $8 \%$ male and $2 \%$ female respondents thought that poor are vulnerable due to their economic status (Fig. 12).

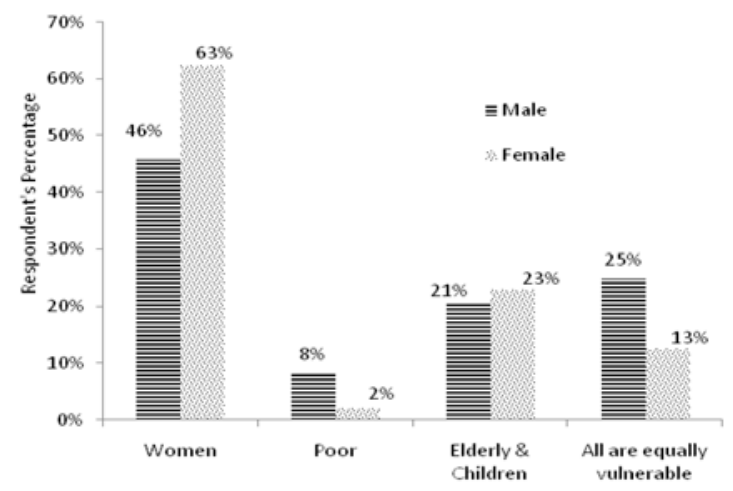

Fig. 12: Responses on gender differentiated vulnerability under climate change induced disasters in Chandani VDC. 
Major problems faced by women only due to climate change induced disasters

Women experience climate change and induced disasters differently than men. The greater mortality ratio of women in any natural calamity clearly depicts their increased vulnerability in any disaster event. The study tried to explore problems faced only by women. In FGD sessions, discussions were carried out regarding to major problems faced by women. Respondents thought women were vulnerable as they faced many problems. Their lack of access to information often restricts them from timely evacuation. Disproportionate burden of disaster preparedness and reduced mobility make them stay in house during disaster periods. Insecurity and lack of privacy made them suffer during and post disaster period severely. Even their traditional dresses like sari restrict their movement during disaster. Lacking the physical strength and managing child at one hand, they can't swim against the strong current generated during the storm surges.

Women have had difficulty in accessing benefits; especially suffer even in enlisting their names in relief distribution list, cash payments and rations, because families are registered for government and insurance purposes in the man's name. Lack of sanitation options in post disaster period made them significantly vulnerable. Water logging made them totally prisoner at their household. It limited all types of socioeconomic activities and interactions, access and control and mobility. Men can migrate to outside for income generation but being women they had to remain in the locality and in absence of male members at house, lead their live in increased vulnerability and insecurity.

\section{Adaptation and coping mechanisms}

Adaptive measures to cope with disaster like flood have not been adopted. KI and FGD respondents said that there are no any adaptive techniques such as early warning system, knowledge transfer through trainings and institutions working only for disaster prevention. According to KIs, People get to know about disaster from their nearer relatives living in hilly district and few from the radio and television, mostly from people to people communication. In the study areas, Women groups and other few organisations are working as community forum whose scope is very limited to social and agricultural work. Therefore, there are not any institutions dealing to cope with changing climate and induced risks.

\section{Adaptation used in infrastructure (House)}

In the Dodhara VDC, 46\% male and 54\% female thought making base height higher can be effective measure in protecting their infrastructure, $42 \%$ male $35 \%$ female built the concrete base for their house and $13 \%$ male $10 \%$ female used galvanized/plastic roof during disasters like heavy rain and floods (Fig. 13).

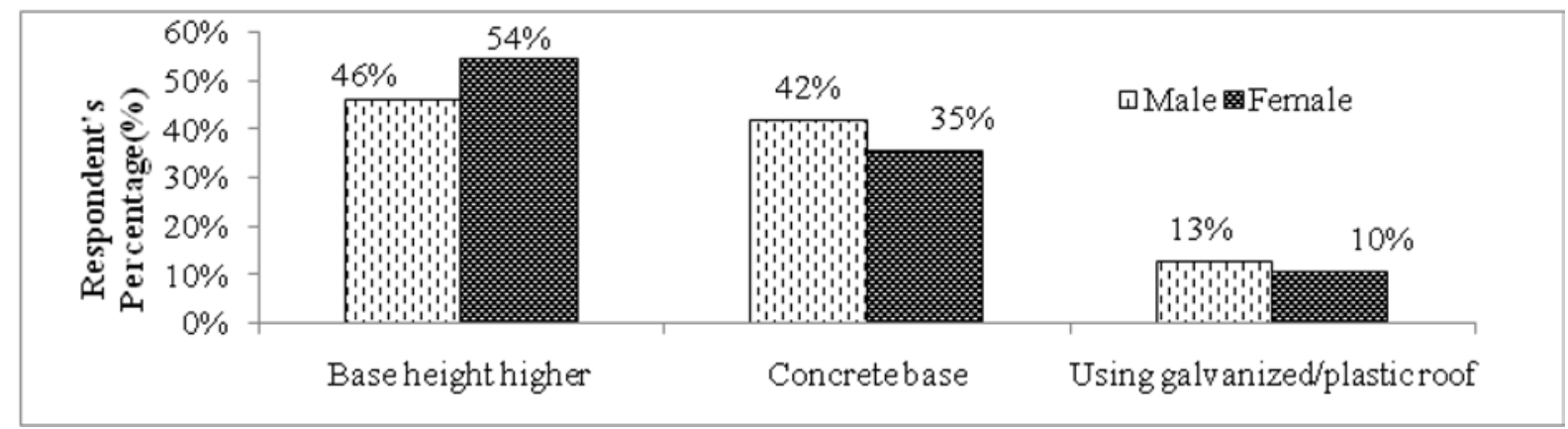

Fig. 13: Responses on adaptive measures used for infrastructure (house) in Dodhara VDC.

In the Chandani VDC, $52 \%$ male and $58 \%$ female thought making base height higher can be effective measure in protecting their infrastructure, $44 \%$ male $38 \%$ female built the concrete base for their house and $4 \%$ male $4 \%$ female used galvanized/plastic roof during disasters like heavy rain and floods (Fig. 14).

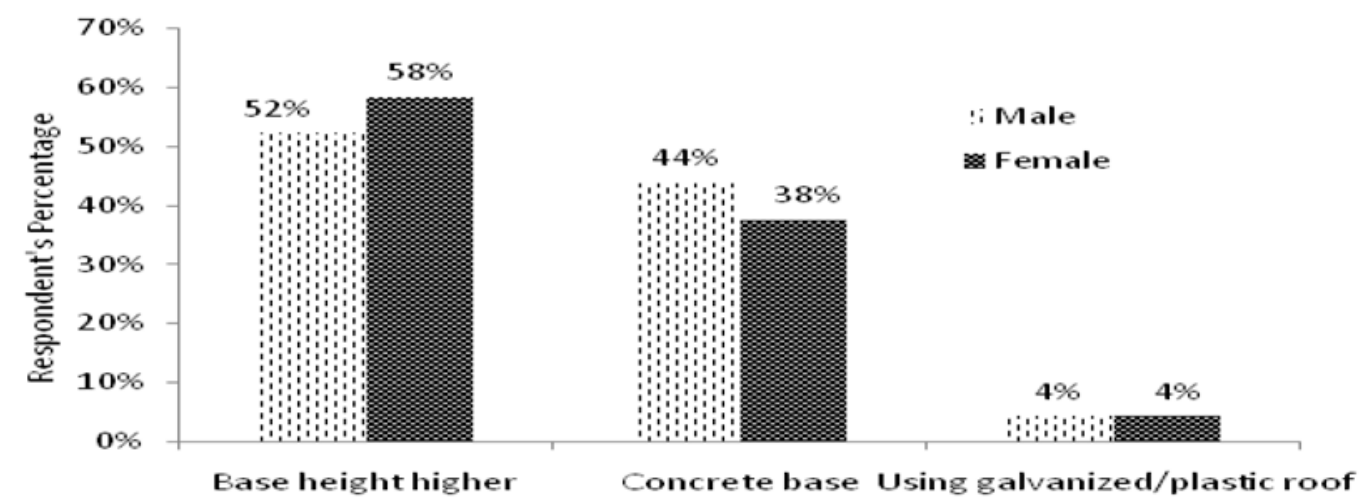

Fig. 14: Responses on adaptive measures used for infrastructure (house) in Chandani VDC. 


\section{Gender differentiated coping measures during disasters}

The respondents were inquired about immediate measures taken at the time of flood disaster during questionnaire survey. In the Dodhara VDC, 19\% male and 19\% female respondents did :nothing/ (stayed at home) and wait for rescue, 33\% male and $25 \%$ female run to high elevation, $15 \%$ male and $13 \%$ female run towards border and 33\% male and $44 \%$ female run towards concrete house to protect themselves (Fig. 15).

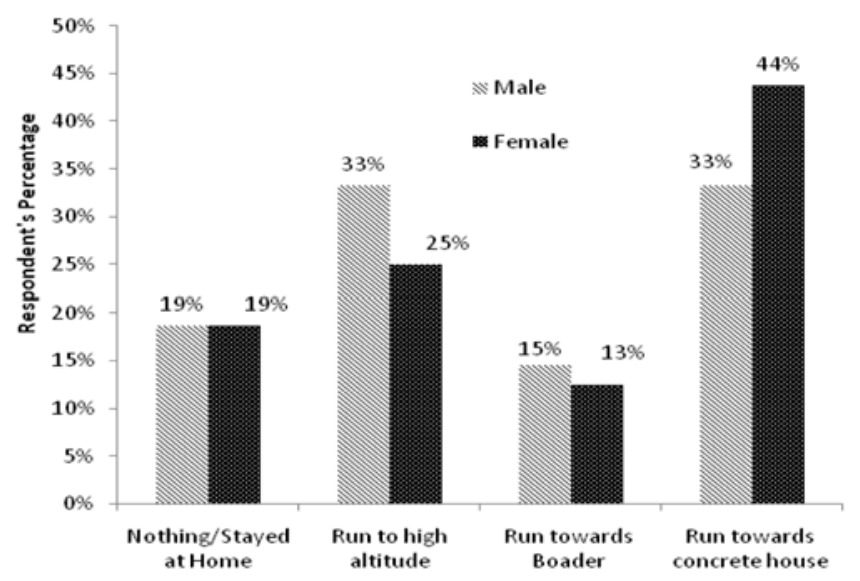

Fig. 15: Gender differentiated coping measures during disasters in Dodhara VDC.

Similarly, in the Chandani VDC, $17 \%$ male and $21 \%$ female respondents did nothing/stayed at home and wait for rescue, $44 \%$ male and 33\% female run to high etevation, $15 \%$ male and $8 \%$ female run towards border and $25 \%$ male and $38 \%$ female run towards concrete house to protect themselves (Fig. 16).

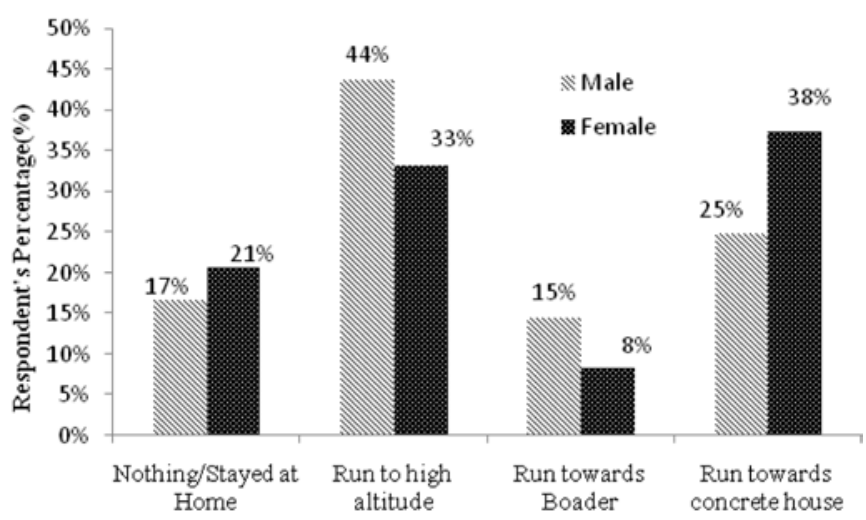

Fig. 16: Gender differentiated coping measures during disasters in Chandani VDC.

\section{Environmental Impacts of flood in Dodhara- Chandani VDCs}

The Mahakali River is one of the major rivers of Nepal that lies in far western region. Recently occurred flood have affected the people living near as well as the surrounding environment. Some impacts that were directly observed during the field visits were also noted. The distinct impact observed was the increase in flood plain of the Mahakali River. During the walk along the bank of the river, it was observed that the river was losing its natural state and enlarging its path. While observing the river, the sand deposits were seen in the banks as well as the middle of the river. The debris deposits containing dead animals, tree trunks, plastics materials carried by the flood were seen. It might contaminate the water of the river affecting the people and aquatic life.

During the flood, water entered in the village and agricultural land have affected directly to the environment. The fertile top soil of land was observed to be covered by the sand and silts brought by the flood. The natural resources like community forests, water sources etc. are also contaminated by the flood water. Dam constructed was also seen damaged by the flood. As the dead animals and waste from upstream was washed during flood, the bank of river contained bulk of unwanted materials creating unpleasant environment polluting air as well as water pollution.

\section{DISCUSSION}

The mean annual temperature is in increasing at a rate of $0.02^{\circ} \mathrm{C}$ per year more or less equal to the national increasing rate of the temperature but is higher than the global average increase given by IPCC (2007). According to Tiwari et al. (2009), average seasonal temperature data analysis showed more prominent rising of temperature in winter ranges from $0.05^{\circ} \mathrm{C}$ in Middle Mountain to $0.02^{\circ} \mathrm{C}$ in Terai region per year which clearly indicates the warming trend in winter is more as compared to summer seasons.

According to a study carried out by Regmi (2009), eastern Terai faced rain deficit in the year 2007/08 by early monsoon and crop production reduced by $12.5 \%$ on national basis. Nearly $10 \%$ of agri-land was left fallow due to rain deficit but the farwestern Terai faced heavy rain with floods, which reduced crop production by $30 \%$. Similarly, the respondents of both VDCs have also experienced the decrease in the production as the pre and post monsoon is decreasing and heavy intensity rainfall during monsoon.

The study found that majority of respondents i.e. $38 \%$ male and $40 \%$ female in the Dodhara VDC and $46 \%$ male and $63 \%$ female in the Chandani VDC identified that women are vulnerable. Similarl studies done in flood prone areas in Bangladesh (CCC 2009) also show that women are the vulnerable groups among all. Guha-Sapir et al. (2004) and Smyth (2005), also found that due to differences in physical skills and lack of ability to swim, the overall mortality rate was more than 60 percent. Though teaching women and girls to swim is not traditional to do so can saved lives in flood-prone areas.

According to the report, women have had difficulty in accessing benefits, especially cash payments and rations, because families are registered for government and insurance purposes in the man's name (Oxfam 2005). Likeilewise some female respondents in the study are also complained that some of them did not get any sorts of relief distributed by the 
government as the name list did not contain their name instead the list contain their husbands name who were far for the labor.

\section{Adaptation and coping mechanisms}

Some of the adaptation measures practicing by the respondents of study area regarding to agriculture are making canal, use new crop varieties and change in sowing time of crop. In the Dodhara VDC, $46 \%$ male and $54 \%$ female and in the Chandani VDC, 52\% male and 58\% female thought making base height higher can be effective measure in protecting their houses during water logging. According to the study carried out by Dixit (2009) flood mitigation like improving drainage, houses on stilts, raising the plinths of houses, etc with other systems (transport, financial, communication, etc) that contribute toward building social resiliency could be an effective strategy for DRR. Nasreen (2008) analyzed existing climate change adaptation policies from a gender perspective. The author tried to show the inter relationship of climate change, disaster and gender in Bangladesh context and assessed experiences, contributions and adaptation strategies of women during and post disaster situations. Similarly, the study conducted in the Dodhara and Chandani VDCs, female respondents shared how they coped with the disaster and post disaster phores.

\section{CONCLUSIONS}

Nepal is highly vulnerable to impacts of climate change due to topographic adversity, climatic complexity and agriculture based economy. People's perceptions of variability in temperature over 30 years were similar with meteorological data records. Climate change and induced disaster like flood are gender specific and women experience changes differentially than men. The study explored the risks to climate change induced disasters from a gender perspective. Females were found more affected in both VDCs as compared to males due to illiteracy, occupation, physical strength, social boundaries, etc. The knowledge regarding to climate change and disasters were also found lacking among females than males. The major environmental impacts observed was the river losing its natural state and enlarging its path, the sand deposits were seen in the banks as well as the middle of the river. Similarly, the fertile top soil of agricultural land was observed to be covered by the sand and silts brought by the flood.

\section{ACKNOWLEDGEMENTS}

We would like to acknowledge New Era Foundation for the research fellowship. We would like to thank the people of Dodhara and Chandani VDCs for their benign co-operation.

\section{REFERENCES}

Arkin, H. and Colton, R. R., 1963, Tables for Statisticians (2nd ed.), Barnes and Noble, Incorporated, New York, 55 p.
CCC, 2009, Climate change, gender and vulnerable groups in Bangladesh. Climate Change Cell, DoE, MoEF; Component 4b, CDMP, MoFDM, Dhaka, pp. ii-vi.

Dankelman, I., Alam, K., Ahmed, W. B., Gueye, Y. D., Fatema, N. and Kutin, R. M., 2008, Gender, climate change and human security: lessons from Bangladesh, Ghana and Senegal, pp. 3-15. WEDO/ABANTU/ENDA. Available at: $\quad$ http://www.gdnonline.org/resources/WEDO Gender_CC_Human_Security.pdf.

Dimitríjevics, A., 2007, Mainstreaming gender into disaster recovery and reconstruction, World Bank Institute, Washington DC, 235 p.

Dixit, A., 2009, Koshi embankment breach in Nepal: need for a paradigm shift in responding to floods, Economic and Political Weekly, Mumbai, v. 44(6), pp. 26-55.

Guha-Sapir, P., Hargitt, D. and Hoyois, H., 2004, Thirty years of natural disasters 1974-2003: The Numbers. Louvrainla Neuve: UCL, Presses Universitaires de Louvrain, pp. 103-120.

IPCC, 2007, Climate Change 2007: synthesis report. Pachauri, R. K., Reisinger, A. (eds.). Intergovernmental Panel on climate change, 103, p.

MOE, 2010, National adaptation program of action to climate change (NAPA), Goverment of Nepal, Ministry of Science,Technology and Envrionment, Kathmandu, $105 \mathrm{p}$.

Nasreen, M., 2008, Impact of climate induced disasters and adaptation strategies: a gender perspective. Climate change impacts and adaptation strategies for Bangladesh. ITN Centre and Dept. of Civil Engineering- BUET, $256 \mathrm{p}$.

NCVST, 2009, Vulnerability through the eyes of vulnerable: climate change induced uncertainties and Nepal's development predicaments, Institute for Social and Environmental Transition-Nepal (ISET-N, Kathmandu) and Institute for Social and Environmental Transition (ISET, Boulder, Colorado) for Nepal Climate Vulnerability Study Team (NCVST), Kathmandu, pp. 13-14.

Neemayer, E. and Plumper, T., 2007, The gendered nature of natural disasters: the impact of catastrophic events on the gender gap in life expectancy, 1981-2002, Annals of the Association of American Geographers, v. 97, pp. 551566.

Nellemann, C., Verma, R. and Hislop, L., 2011, Women at the frontline of climate change: gender risks and hopes, a rapid response assessment, United Nations Environment Programme, GRID-Arendal, 6 p.

Oxfam, 2005, The tsunami's impact on women: Oxfam briefing note, Oxfam International, March 2005, pp.10-14. 
Pradhan, E. K., West, K. P., Katz, J., Leclerq, S. C., Khatry, S. K. and Shrestha, S. R., 2007, Risk of flood-related mortality in Nepal Disasters, v. 31, pp. 57-70.

Regmi, H. R., 2009, Effect of unusual weather on cereal crops production and household food security, Jour. Agriculture and Environment, v. 8, pp. 20-29.

Smyth, I., 2005, More than silence: the gender dimensions of tsunami fatalities and their consequences. WHO Conference on Health Aspects of the Tsunami Disaster in Asia, Phuket, Thailand, 4-6 May 2005, pp. 29-60.

Tiwari, K. R., Awasthi, K. D., Balla, M. K. and Sitaula, B .K., 2009, Local people's perception on climate change, its impact and adaptation practices in Himalaya to Terai regions of Nepal, Institute of Forestry, Tribhuvan University, Pokhara, Nepal, pp. 4-5.
UNDP, 2010, Human development report 2010. Available at www: http://hdr.undp.org/media/HDR_2010_EN_ Tables_reprint.pdf [Assessed 2014-09-19], 38 p.

UNISDR, 2009, ISDR: Terminology - basic terms for disaster risk reduction. [Accessed 20 April 2014] http://www. unisdr.org/eng/library/lib-terminology-eng\%20 home. htmss

Upreti, B. N., Rai, S. M. and Yoshida, M., 2007, Geomorphological observations surrounding Lukla, eastern Nepal Himalaya. Abstract, Jour. Nepal Geol. Soc., v. 36 (Sp. Issue), pp. 29-29. 